\title{
Managing School Voucher Program in Developing Country: Lesson from Smart Indonesia Program
}

\author{
Budi Setiyono and Wisnu Pradoto \\ Diponegoro University
}

\begin{abstract}
In order to pursue universal access to education, the Indonesian government has arranged a number of funding assistance programs for the people, especially for the poor. Among of the programs is the Smart Indonesia Program (Program Indonesia Pintar--PIP). In order to make the program takes place, three ministries namely the Ministry of Education and Culture (Kemendikbud), the Ministry of Social Affairs (Ministry of Social Affairs), and the Ministry of Religion (Kemenag) are assigned by the government to implement this program.

PIP aims to help school-age children from poor or vulnerable families and families in remote areas to be able to access education services up to high school, either through formal channels (to complete high school / vocational school) or non-formal channels (i.e. standardized courses). This program scheme provides cash assistance for pupils distributed through the Indonesia School Voucher (Kartu Indonesia Pintar-KIP) so they can complete the 12-year compulsory education.

By evaluating the program at five cities and regencies, this study intends to evaluate the implementation of the program. This study explores the PIP policy, and recognizes the obstacles, challenges, weaknesses, and potentials encountered in implementation of the policy. The research was carried out in related institutions, several NGOs, and the general public with an explorative qualitative approach. This research recommends to the government to improve the design and implementation of PIP. The recommendations also include the division of roles and patterns of cooperation between government agencies and other parties in implementing the program.
\end{abstract}

Key words: universal education, social welfare policy, scholarship subsidy, national development, school voucher. 


\section{Background}

In 2015, in line with President Jokowi's nawacita program, the Indonesian government launched a 12-year compulsory education program, by formulating voucher education subsidy called Program Indonesia Pintar (PIP), aiming that school-age children can take free education up to high school. This program is a continuation of the implementation of Law Number 20 / 2003 concerning the National Education System, which stipulates that education funding is a shared responsibility between the government, regional/local government and the community. This means, education funding does not have to be fully borne by the people, but there are subsidies from the government (central) and regional government.

Long before the existence of PIP, to help finance public education, the Indonesian government had created an education subsidy program by channeling BOS funds (School Operational Costs), and also providing scholarships for poor students such as BM (Bantuan Mahasiswa Miskin Berprestasi--Poor University Student Assistance) and BSM (Bantuan Siswa Miskin--Poor Student Assistance). These scheme, especially BOS and BSM cover part or all of the education costs that must be borne. Through Presidential Instruction Number 7 of 2014, BSM was changed to PIP implemented by three ministries namely the Ministry of Education and Culture (Kemendikbud), the Ministry of Social Affairs (Kemensos), and the Ministry of Religion (Kemenag).

When referring to Presidential Instruction Number 7 of 2014, the purpose of the PIP is to help school-age children from poor / vulnerable poor / remote families continue to get educational services until graduating from secondary education (senior high school), both through formal and non-formal education channels. Through this program the government seeks to prevent students from dropping out of school, and is expected to be able to attract dropouts to return to continuing their education. PIP is also expected to ease the personal costs of education of students, both direct and indirect costs. ${ }^{1}$

In reality, the implementation of the compulsory education program still shows suboptimal results. Until now, the compulsory education program has not really waived the cost of education as a whole. Parents still have to buy textbooks, extracurricular activities fees and (in part) pay building fees. In addition, the implementation of this program also challenged a number of problems in various regions.

Data obtained from Central Bureau of Statistic (BPS 2018) shows that the net enrollment rate at the junior secondary level is still $78.84 \%$ and the high school level is only $60.67 \%$. This figure shows that the government has not been successfull in realizing the overall citizens who graduated from elementary school to junior high school education ( 9 years education) and junior high school graduates to get senior high school (12 years of education). This shows that PIP and the overall education policy scheme have not yet succeeded in realizing 12 years of compulsory education. If the policy runs properly, the pure participation rate should reach $100 \%$.

${ }^{1}$ see https://indonesiapintar.kemdikbud.go.id/ 
Of course, PIP is not a single factor that determines school enrollment rates. There are other determining factors such as the availability of infrastructure, devices, and also the availability of teachers. However, it is important to see how this PIP contributed to increasing school participation.

\section{Aims}

This research identifies the program characteristics, priorities and strategies developed in the preparation and implementation of PIP, and also overview public involvement. In addition, this study also aims to evaluate the obstacles and limitations that exist in the implementation of PIP, especially in terms of coordination, socialization, verification process, accuracy of targets, fund distribution, disbursement and utilization of fund, complaint and troubleshooting, and satisfaction with the program.

\section{Method of the research}

This study uses an exploratory approach, which aims to explore concern phenomena or problems. Data collection is done through in-depth interviews, using interview guidelines, through focus group discussions (FGD), observations, and literature studies by collecting data in the form of government reports, scientific articles, books, and statistical data related to research topics. The data are mainly obtained from collections owned by: Ministry of Education and Culture (Kemendikbud), the Ministry of Social Affairs (Kemensos), and the Ministry of Religion (Kemenag), Regency / City Education Agency, local council, Regency / City Planning Agency (Bappeda), and technical institutions for the provision of Indonesian education, Social Service, and Regency / City Statistic Agency.

The researcher visit and become guest researcher at the agencies above. In addition to obtaining data, the researcher conducted in-depth interviews with several key informants who were considered to have sufficient knowledge of the research topic by asking structured questions. They were chosen by purposive and snowball techniques. Furthermore, limited observation was also carried out in PIP implementing agencies in five provinces. Focus group discussions (FGDs) are conducted with competent officials and academics.

Table 1. Locus Sampling

\begin{tabular}{|l|l|}
\hline \multicolumn{1}{|c|}{ Provinsi } & \multicolumn{1}{c|}{ Regency/City } \\
\hline Yogyakarta & Yogyakarta (urban) \\
\hline Central Java & Klaten (rural) \\
\hline East Java & Blitar (rural) \\
\hline West Sumatera & Padang (urban) \\
\hline Eastern Kalimantan & Balikpapan (urban) \\
\hline
\end{tabular}


The study was conducted in five sample districts / cities, namely Yogyakarta City, Blitar Regency, Klaten Regency, Balikpapan City, and Padang City (see Table 1). The five regencies / cities are chosen by a free draw, yet taking into account of rural vs urban area, and java island vs non-java island region.

\section{Voucher Education Concept}

Education takes an important part in achieving efforts to realize people's welfare. By education, there is a process of building quality human capital, by which the people have the ability to think and act in making plans, formulating programs and activities, as well as implementing them personally and collectively (Katz 2010). In this regard, many governments around the world, carry out this human capital theory, by making investment on education sector so that their citizens could involve in the process of lifelong learning so that they can get a job. This is not only related to the purpose of earning income, but also self-actualization. Human capital theory suggests that by increasing skills and abilities will enable people to act in new productive ways, and assume that investment in education will improve the quality of the workforce, which in turn will increase economic growth and overall national productivity (Becker 1964).

Teachers are gradually given insight into the importance of the interconnection between academic mastery and work skills so that schools become responsible places for the success of students in careers and make the national economy competitive in the global market. The government determines managerial, curriculum, accountability, inspection, testing, and targets, and educational objectives. This is done so that schools can facilitate the development of respectable forms of knowledge as credentials that can be exchanged for employment, income and status (Tomlinson 1997).

To make this concept works, the government needs to ensure that every citizen can have access to the highest possible education. Countries like Germany even waive the cost of education from birth to doctoral level. While other developed countries like Australia provide free tuition fees up to the Senior High School level and provide a Higher Education Credit (HEC) financing scheme for anyone who wants to study. While developing countries generally try to educate their people by freeing up school fees to the high school level (compulsory education for 12 years). Compulsory education is intended to ensure that all people in the country get universal education standards and access to jobs in accordance with government regulations (Katz 1976: 8$10)$.

However, related to the above, the condition of the education system in developing countries faces many complex problems. As stated by Gauri \& Vawda (2003: 1-2), many poor countries have a budget deficit that makes it impossible to provide fully free education. There are also gaps in access and significant differences in the ability to pay between children from rich and poor families. Meanwhile, many middle-income countries have almost reached universal coverage in primary and secondary education, but the quality of teaching and learning is still low, especially for 
the poor. Other problems relate to systems that ignore family problems because of unresponsive policies. In this situation, in the end, developing countries eventually face with low school participation rates.

\begin{abstract}
Developing countries are also trapped in conventional education governance systems where the central ministry of education designs a national curriculum, finances education from the general budget, and pays capital and operational costs directly. This has several consequences such as centralizing all managerial and staffing decisions, negotiating teacher salaries with national trade unions, rewarding and promoting teachers based on negotiated criteria, making teachers are not motivated, unresponsive school administrators to the families of students, and passive parents who have no choice but to enroll their children in schools they do not like (Gauri \& Vawda 2003: 2).
\end{abstract}

In recent decades, several countries in the world have introduced education policy reforms to address school problems (OECD 2017: 4). The reforms, on the one hand, are aimed at making it easier for parents to send their children to the school of their choice. At the same time, schools are given greater autonomy to enable school administrators to be more responsive in making policies related to resources, curriculum, assessment, school acceptance, and discipline. In line with this, the education system has also allowed private schools to be integrated into the public education system as schools that are identical to public schools or as fully independent schools that receive some public funding.

Regarding this development, educational vouchers or systems have become the object of intense political debate. Theoretically, the purpose of the school voucher program consists of three simultaneous things, namely: (1) enabling parents to choose schools, (2) creating strong incentives for schools to increase enrollment, and (3) granting school management autonomy to be responsive to demand service users (students) (Gauri \& Vawda 2003: 4-5).

\title{
Implementation of PIP Voucher Education Program
}

The PIP program is implemented through cross-sectoral coordination in collaboration based on the main functions and tasks of each institution. The institution responsible for the distribution of PIP funds is the Ministry of Education and Culture in collaboration with various relevant government agencies, especially the Ministry of Social Affairs. Whereas the distribution of funds was made to banks and other service institutions appointed by the government on the recommendation of the school where the PIP recipients studied.

For coordinating activities, a Program Implementation Unit (UPP-Unit Pelaksana Program) at every level of government from the central to the city/regency level, was formed with the authority to provide guidance, supervise, and implement the 
program. The UPP is chaired by a department / social service agency and consists of various relevant government agencies such as statistic bureau, department of education, and planning agency.

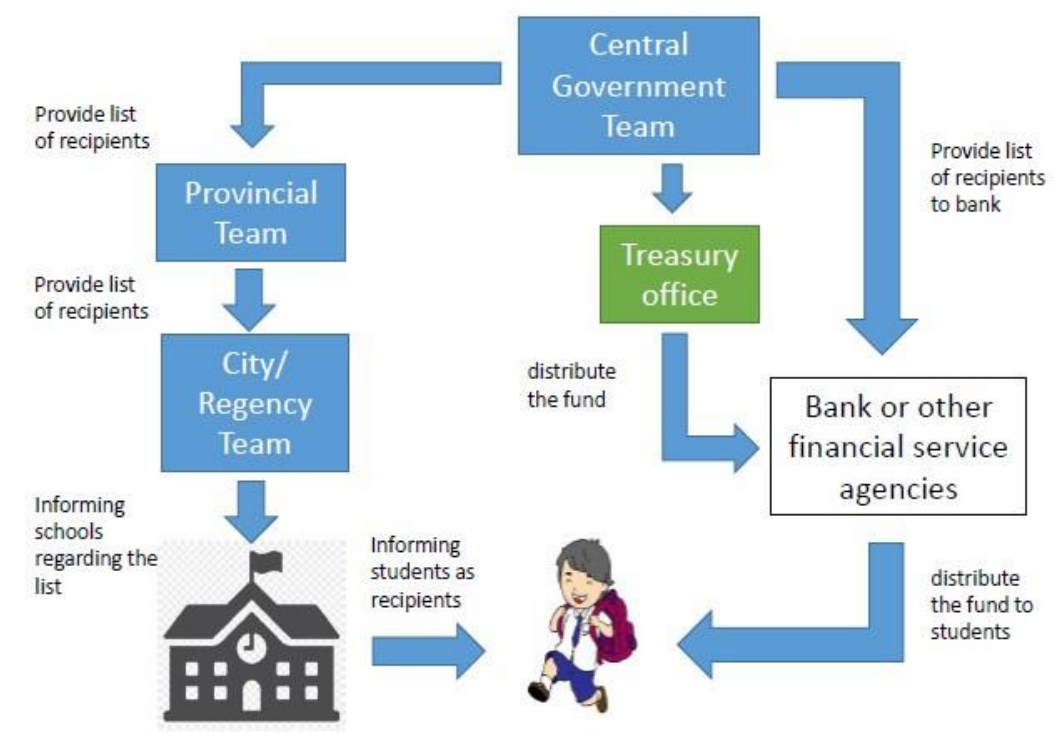

Figure 1: PIP distribution mechanism

Source: Kemendikbud (2014)

The government regulates number of restrictions on the use of funds to pay noneducational needs, such as the prohibition to buy cellphones, food, or electronic devices. This restrictions, however, have been criticized by NGOs, teachers, media, and parents. In all research area, informants suggest that such restriction is not applicable to all situation. In some cases, students need devices such as cellphone so that they can communicate with their teachers and access information on the internet to carry out assignments from their teachers.

\section{Coordination Issues}

Various institutions play different role in the implementation of the PIP program. First, Bureau of Statistic (BPS) provides data on poor students. Second, the ministry of education hold the authority to issue decree for periodic withdrawal of PIP money. Third, the education office in the city / regency is tasked with conducting supervision in the field if there are obstacles. Fourth, the school is collecting data on the list of students who are entitled to receive PIP assistance. Fourth, banks (BRI and BNI) play the role of PIP fund channeling gate.

The process of distribution consists of several steps. First is the issuance of decree from the central government team to provincial then district level and schools, then the school notifies students or parents / guardians that they are recipients of the voucher. Furthermore, parents / guardians and students take the funds that have been available at 
the Bank. The regional/city education office has the duty to supervise if there are problems with the distribution of funds. If there are problems related to inaccurate data, or the existence of poor students who are not registered, then the problem is overcame by several stages from the school level to the City / Regional Education Office.

In general, informants on all locations complain about the weak coordination, vertically across levels of government and horizontally between involved institutions. All informants also disparage the slow responsiveness to instructions from institutions the parties involve. According to informants, this situation is influenced by several factors, namely (i) lack of incentive for coordination and operational meetings from the provincial to district level (ii) bureaucratic processes that are still convoluted (iii) confusion in understanding of the objectives and nature of the PIP program.

In the early days, in particular, the poor coordination brought about the slow disbursement process. This happens because the information about the disbursement procedure has not been fully disseminated properly. Many parents do not know how to withdraw funds. In addition, officials in the implementing agencies also do not fully understand the procedures. In Yogyakarta, for example, when the withdrawal of PIP funds falls, not all recipients disburse the funds within the specified time limit. Aside from slow process of disbursing funds, this is also due to the negative perspective on the program itself which create a bad stigma for recipients because it is positioned as a poor person. The local Education Office tried to overcome the problem by demanding the Bank, as the distributor of funds, to open a stand in the Education Office yard. This

then accelerated step and makes it easier for parents / guardians of students to take these funds.

The issue of weak coordination also took place in the City of Balikpapan. This is due to the confusion of the parties related to the change in the scheme from previous program (BSM) to PIP. At the beginning of the program, many voucher cards did not reach PIP recipient houses. This happens because the cards are distributed through multiple level parties from regency level to sub-district to village and eventually to recipients. In the meantime, many recipients have changed their addresses and moved out from the village.

In Blitar, one informant said that coordination between agencies was very weak, because everything seemed to be regulated by the central government. Not infrequently, for example, when people complained to the Local Social Service, they was advised to report to the Education Office, and from the Education Office was told to report to the center government.

\section{Socialization of the Program}

Socialization of PIP for educational institutions and the general community is carried out at the national, provincial, district / city, district and village levels. In this case, educational institutions include public schools under the auspices of the Ministry of Education and Culture and the Ministry of Religion as well as the private sector. Meanwhile, the socialization to community is specifically directed to PIP recipients, 
based on data compiled by the Social Service and the Communication and Information Office in each regency and city.

At the provincial level, socialization is given by the Governor through a coordination meeting with the mayors/regents, which is then followed up by the relevant offices within the regency/city. Then the implementation of the socialization at the district and city level was carried out by the Social Service Agency, together with the Education Office and the Bank's channeling institutions or other channeling institutions recommended by the government. The socialization process is carried out typically by gathering all PIP operators in each school. Furthermore, operators at the school level provide socialization to students who are registered with the District Education Office. The school operator also conducts socialization to the parents' association.

When there are children who want to get a PIP voucher but are not registered, they can register through their school, by attaching a Certificate of Inadequacy from the Village and District Institutions. Through school recommendations the children can receive the same educational assistance and be registered as a PIP member.

The content of socialization focused on the technical implementation of the program such as verification, voucher distribution, disbursement schedule, and the amount of funds that would be received by PIP beneficiaries. The explanation also contains information about what PIP is, PIP background, PIP objectives and PIP criteria. Besides being carried out to explain PIP to the community, this socialization was also aimed at increasing the community's participation in overseeing PIP.

Some regions, however, reportedly did not conduct socialization in the form of meetings, but directly executed PIP distribution based on data compiled by the Social

Service. In Blitar and Balikpapan districts, for example, the local Education Office claimed that they had never conducted socialization, but instead immediately disbursed the money after an order from the ministry to accelerate the disbursement. The mechanism is that the Education Office comes to the sub-district (kecamatan) with the Bank to immediately implement the disbursement by opening a stand at the kecamatan office.

\section{Verification Process}

The basis for determining the PIP recipients is the results of the 2015/2016 Socioeconomic Survey (SUSENAS) from BPS which has been updated related to another Program called the Family Hope Program (PKH-Program Keluarga

Harapan). The BPS sent the list of poor family name and address to the district Social Service Agency. In accordance with the 2015 PIP Program guidelines, the data is then followed up with verification by Social Service Agency officials who are deployed to villages and school operators or through village consultation with all elements of the community.

The accuracy of this BPS data, however, has been complained in several areas. In Padang City, as some informants maintain, the data did not accommodate many poor students, so the local Education Office had to re-propose names with categories including: (i) orphans; (ii) abandoned children living in orphanages; (iii) children with 
special needs; and (iv) children whose parents go to prison. The data is then included in the Integrated Database issued by the Ministry of Education \& Social's Integrated Data Center. After completion and validation by the school, the data is entered into the PIP website. In Balikpapan City, the mechanism of the verification process is in the hands of schools. The master data is given by the Social Service Agency, then the school operator verifies it. If there are poor students who are not registered, the school can propose to be added to the list of additional recipients to PIP website.

\section{Accuracy of Target}

In general, this research found that the PIP program is very helpful for poor students to continue their education. In Padang and Blitar, for example, informants reported that this program could help many poor children who had dropped out of school. However, this study found that there were several obstacles encountered. First, there are parents / guardians who underestimate the amount of the program's financial assistance because it is considered too little. In 2015 until now 2019, assistance for elementary school students was Rp 225,000 per semester, junior high school at Rp 375,000 per semester, and high school at Rp 500,000 per semester. The small amount makes them, especially those who are not too poor, reluctant to take the money. Not surprisingly, in the city of Yogyakarta, for example, every year, the absorption of PIP funds is only below $90 \%$. According to the informants there, this happened because parents who were somewhat able, did not take the funds.

Furthermore, in all research areas, it is reported that there are political intervention from members of the national and local parliament in determining the list of recipients. In fact, after being verified it was found that the additional list consist of a number of students who were not eligible to receive PIP. Unfortunately, almost every region stated that they were unable to reject the intervention of the parliament members, even though

they knew the additional PIP recipients were actually not eligible, leading to the rise of protest from the people.

Updating the data is also a crucial issue. In Blitar City, for example, there were reports regarding a number of students who were listed as poor but apparently were already well-heeled because the recipient's data was not updated. The case is unveiled because the children did not take PIP money, then the school operator checked the student's situation and reported it to the Education Office and the Social Service Agency. Another obstacle is related to students who have already graduated. Many school operators find it difficult to discover the identity of children who have already moved from schools so that funds are not absorbed.

\section{Fund Distribution}

As mentioned above, the distribution of PIPs is executed through banks or other designated institutions. In this context there are at least two prominent issues. First, remembering that beneficiaries are those who come from poor groups, not all recipients know how to make bank accounts. In all research sites, it was reported that many PIP recipients had to go back and forth to the bank to complete the requirements because the documents requested by the bank were incomplete. Therefore, the Education Office 


\section{8-20 October, 2019 BUDAPEST, HUNGARY}

official or the school operator sometimes has to act as a facilitator between the bank and parents to make students' bank account.

The second problem is related to the fact that the location of the bank is, sometimes far from where the students' family lives. So that in some cases, the cost of withdrawing money is actually greater than the amount of the aid itself. In Blitar and Padang, for example, some students have to go 10 kilometers to the bank and spend more than 4 hours. Fortunately, the Bank is willing to open a special teller for PIP disbursement on weekdays between 3 and $5 \mathrm{pm}$, and Saturdays start from morning to 1 pm.

\section{Disbursement and Utilization of Funds}

Despite some problems, the disbursement process was reported smooth in five research areas. Some informants in Klaten and Blitar stated that the disbursement sometimes got delay because the teller at the bank that served students was only one person. So, the service is not optimal. Another problem deal with the inappropriate use of money. In several research areas, such as Yogyakarta, Blitar, Klaten and Samarinda, informants informed that a lot of PIP assistance money was used by parents of students for noneducational needs such as to buy food, cell phone credit, cigarettes, and to pay debts. In the city of Yogyakarta, informants complained that PIP was unable to inhibit dropout rates and did not resolve the issue of education funding. This is because many parents use these funds for consumptive needs. Many students remain in arrears to pay for education such as tuition fees, or even do not want to pay for education and also buy school uniforms because parents / guardians of students use money for non-educational needs. In Blitar, even informants told us that many students who received PIP did not pay school tuition fees at all because the money was used to buy the necessities of their parents' lives

\section{Complaints and Troubleshooting}

The complaint mechanism for the implementation of PIP seems to be inefficient considering that the mechanism is mainly only provided by the central government through a web page, email, telephone, and application report. At local level, however, there was no specific PIP complaint unit. This causes unclear mechanism for dealing with the community when they want to solve problems regarding PIP. In some areas such as Padang, Blitar, Balikpapan and Klaten, the community submitted complaints to school operators, after which they were only submitted to the Education Office. However, this is not very efficient because the school operator itself has other main routine work, besides the operator also sometimes becomes the object of complaints.

\section{Satisfaction with the Program}

Assessment to the level of satisfaction of the parties to the implementation of PIP is undertaken through focus group discussion (FGD) at the Regency / City level. Generally, all informants stated that the funds provided were inadequate to meet the educational needs of students. This is based on the fact that the provision of the funds 
has the same universal amount allover Indonesia, even though each city or district has different numbers of needs or purchase prices. In addition, the amount of funds is considered too small, namely the elementary level of Rp. 450,000, - / year, Rp. 750,000, - / year, and Rp. 1,000,000 per year, so it is considered unable to cover the school's annual needs. Ideally, according to several informants, the costs given should be at least double the amount currently provided. In Yogyakarta Province for example, the provincial government provides a supplementary program with the 'smart card' program for high school students. The amount of assistance provided by smart cards is greater than PIP assistance, which is Rp. 1,500,000. This smart card is intended to cover the poor but is not included in the PIP recipient list.

\section{Conclusion}

Historical concepts, procedures, positive aspects and weaknesses of PIP as an education voucher model in Indonesia have been discussed. In general the implementation of PIP can provide incentives for poor students to study. However, there are various problems that arise in the program. Among them is concerning the existence of negative perceptions of the program of some government officials from the district level to the village, NGOs and the Media. They consider that PIP only makes people lazy and consumptive. Therefore, some stakeholders encourage the PIP program to be replaced with the community empowerment program needed by the people, especially thos in rural area.

Analysis of the research results and opinion of informants in several research areas suggested some improvements. First, it is necessary to evaluate a number of restrictions on the use of funds, such as the prohibition to buy cellphones that need to be revoked because now is the era of information technology and cell phones are the needs of school children as learning media.

Second, there needs to be a monitoring mechanism, evaluation and reporting at the local level so that all parties can resolve the existing problems as quickly as possible. If the reporting mechanism is only at the center, there are difficulties in terms of the range of control being too far away. Third, mechanisms need to be made so that there is a marking between recipient children who are performing well in their school and those who are not performing, so that it is expected to be able to spur children to be more enthusiastic about getting achievements.

\section{Refference}

Becker, G. (1964) Human Capital. New York: National Bureau of Economic Research BPS (Badan Pusat Statistik) (2006-11) Statistic Indonesia, Jakarta: BPS [online, accessed 3 November 2016, address: http://www.bps.go.id/].

Bo Rothstein (2001) The Universal Welfare States as A Social Dilemma, Rationality and Society May Vol. 13 (2), p. 213-233. 


\section{World Conference on SOCIAL SCIENCES}

\section{8-20 October, 2019 BUDAPEST, HUNGARY}

Bryson, L. (1992) Welfare and the State, London: MacMillan Press.

Department for International Development (DFID) (1999). "International Development Target Strategy Paper: Economic Well-Being. Consultation Document". in Norton, A., Conway, T., \& Foster, M. (2001). Social Protection Concepts and Approaches: Implications for Policy and Practice in International Development. London: Overseas Development Institute.

Esping-Andersen, G. (1999) Social Foundations of Postindustrial Economies. Oxford: Oxford University Press.

Esping-Andersen, G. (1990) The Three Worlds of Welfare Capitalism Princeton :NY University Press

Ferragina, E. and Seeleib-Kaiser, M. (2011). "Welfare regime debate: past, present, futures". Policy \& Politics: Vol. 39 (4). pp. 582-21.

Gauri, V. and Vawda, A. (2003) 'Vouchers for Basic Education in Developing Countries A Principal-Agent Perspective', World Bank Policy Research Working Paper 3005, (March 2) [online, accessed 10 June 2019, address: https://pdfs.semanticscholar.org/c723/3bd4c6931170ecbd3b464cdd154c66333 002.pdf]

Gauthier, D. (1990) Moral Dealing: Contract, Ethics, and Reason. Cornell: Cornell University Press.

ICW (Indonesia Corruption Watch) (2018), Hasil Survey Exclusion Error Program Indonesia Pintar Jokowi-JK, [online, accessed 4 Agustus 2019, adddress: https://www.antikorupsi.org/sites/default/files/hasil_survey_kartu_indonesia_p intar.pdf]

Katz, M. S. (1976) A History of Compulsory Education Laws, Bloomington, Ind.: Phi Delta Kappa.

Katz, M. B. (2010), Public Education as Welfare, Dissent Magazine, Vol Summer 2010. [online, accessed 3 September 2018, address: https://www.dissentmagazine.org/article/public-education-as-welfare]

Kemendikbud (2014), Kartu Indonesia Pintar (KIP), Bahan Rapat di Kementrian Koordinator Pembangunan Manusia dan Kebudayaan, online, accessed 12 Agustus 2019, address: https://slideplayer.info/slide/3247564/]

Kemenkes (2015) Laporan Akuntabilitas Kinerja Kementrian Kesehatan Tahun 2015, Jakarta: Kemenkes

Kenworthy, L. (1999). "Do Social-Welfare Policies Reduce Poverty? A Cross-National Assessment", Social Forces Vol 77 (3), pp. 1119-1139.

Kenworthy, L. (2011) Progress for the Poor, Oxford: Oxford University Press, USA. Lindbeck, A. (2006) "The Welfare State - Background, Achievements, Problems", FN Working Paper No. 662, Research Institute of Industrial Economics [online, accessed 20 August 2019, address: http://www.ifn.se/Wfiles/wp/wp662.pdf].

Maidment, R. A., Goldblatt, D. S., and Mitchell, J. (eds.) (1998). Governance in the Asia-Pacific. Psychology Press.

Mares, I. (2003), The Politics of Social Risks, Cambridge: Cambridge University Press. Mashall, TH (1961) "The Welfare State: A Sociological Interpretation", European Journal of Sociology, Vol. 2 (2/Dec), pp. 284-300. 
Marwati Dj. P., dan Notosusanto, N. (1984), Bangsa Indonesia, Jakarta: Balai Pustaka. Nozick, R. (1974) Anarchy, State and Utopia. New York: Basic Books.

OECD (2014): PISA 2012 results: Creative problem solving: Students' skills in tackling real-life problems (Volume $\mathrm{V}$ )

OECD (2017), School choice and school vouchers: An OECD perspective, Paris: OECD. [online, accessed 2 August 2019, address: http://www.oecd.org/education/School-choice-and-school-vouchers-anOECDperspective.pdf]

Pierson, C. (1998) Beyond the Welfare State: The New Political Economy of Welfare, Cambridge: Polity Press.

Rawls, J. (1971) A Theory of Justice. Harvard: Harvard University Press.

Setiyono, B. (2017), Perbandingan Gerakan Anti Korupsi Antara Korea Selatan dan Indonesia (Buku Ajar), Semarang: LP2MP UNDIP.

Scott, I. (2010). The Public Sector in Hong Kong. Hong Kong University Press.

TI-Transparency International (2013), Corruption Perception Index, [online, diakses 10 Oktober 2014, address: http://cpi.transparency.org/cpi2013/]

Tomlinson, S. (ed.) (1997) Education 14-19 Critical Perspectives. London: Athlone.

Undang Undang Dasar Negara Republik Indonesia Tahun 1945.

Undang-Undang Republik Indonesia Nomor 13 Tahun 1998 Tentang Kesejahteraan Lanjut Usia.

Undang-Undang Republik Indonesia Nomor 36 Tahun 2009 regarding Kesehatan. Undang-Undang Republik Indonesia Nomor 4 Tahun 1992 tentang Perumahan dan Pemukiman.

Undang-Undang Republik Indonesia Nomor 20 Tahun 2003 regarding Sistem Pendidikan Nasional.

World Bank, (2014), World Development Indicators, [online, accessed 20 April 2019, address:

http://databank.worldbank.org/data/views/reports/tableview.aspx?isshared=tru e]

World Bank (2015), GDP per capita [Online, accessed 10 October 2019, address: http://data.worldbank.org/indicator/NY.GDP.PCAP.CD] 